\title{
The Differences in School-Related Attitudes of Middle School Students in School Sports Club
}

\author{
Eun-Ju Lim ${ }^{1}$ and Deajung Lee ${ }^{2}$ \\ ${ }^{1}$ Chonbuk National University, Korea \\ ${ }^{2}$ Jeonju Peonghwa middle school, Korea \\ ${ }^{1}$ modernii@hanmail.net, ${ }^{2}$ dleownd23@hanmail.net
}

\begin{abstract}
The purpose of this study is to analyze the difference of school attitude of middle school students participating in school sports club and to identify the necessity of school sports club activities. For this purpose, 520 middle school students who participated in school sports club and 485 middle school students who did not participate were selected as research participators. The difference in school attitude was analyzed by the presence of school sports club, participation period, the frequency of participation per week, and the number of participation in competitions. Collected data were statistically processed by using the SPSS 25.0 program. Exploratory frequency analysis, reliability analysis, $t$-test, one-way ANOVA were conducted and verified by the post hoc test. As a result, significant differences are as follows: First, all sub-factors of school attitude of middle school students showed differences as per their participation in school sports club. Second, all sub-factors of school attitude of middle school students showed differences as per the participation period of school sports club. Third, all sub-factors of school attitude of middle school students, except school friend factors showed differences as per the participation frequency of school sports club. Fourth, all sub-factors of school attitude of middle school showed differences as per the participation frequency of school sports club competitions. According to these results, the followings are concluded: First, school sports club policy should be established from a long-term perspective. Second, the number of school sports club competitions should be increased. This study is significant as an empirical data that participation in school sports club positively affects the formation of school attitudes of middle school students.
\end{abstract}

Keywords: Middle school student, School sports club, Participation experience, Schoolrelated attitudes, ANOVA

\section{Introduction}

School sports club is a student-led sports organization [1] that promotes health and forms a vibrant school atmosphere through the voluntary participation of the same school's students with a hobby in sports activities, and it has been rapidly growing through the national pilot project since 2007. Moreover, it has been decided as one of the four main tasks of the primary and secondary school sports promotion plan [2] (strengthening physical education in curriculum, expanding school sports club and revitalizing sports league, motivating students to participate in sports activities, and establishing infrastructure for student sports activities).

Article history:

Received (June 5, 2020), Review Result (July 8, 2020), Accepted (August 12, 2020) 
Therefore, the number of students who participate in school sports club for more than 17 hours has been steadily increasing to 3,314,820 in 2013, 3,787,401 in 2014, and 3,878,938 in 2015. Accordingly, the students participating in school sports club league showed positive changes in school life adaptability and personality, and the activation of school sports club and the degree of school violence were found to have a negative(-) relationship [3][4]. In particular, there are many studies reporting that adolescent sports activities are whole-person education that plays an important role in morality and personality by improving the positive aspects of students' personality, empathy, and communication skills, while reducing delinquent traits so that there is a growing social expectation of personality education through school club activities [5][6]. Other studies [7][8] also reported that students develop personality and social factors when they participate in school sports club in the medium and long term. However, studies on school sports club activities and school attitudes that is school-related attitudes are very insufficient, given that a school is the space where students spend the most time and have a great influence on the formation of attitudes including their personality. This study aims to analyze the differences in the school attitude of middle school students participating in school sports club so as to identify the necessity of school sports club activities at school as a venue for whole-person education that contributes to growing and developing them into healthy citizens with a positive school attitude. To this end, the research hypotheses are as follows. First, their participation/non-participation in school sports club will affect middle school students' attitudes towards school. Second, the participation period of school sports club will affect middle school students' attitudes towards school. Third, the frequency of participation per week in school sports club will affect middle school students' attitudes towards school. Fourth, the number of school sports club competitions will affect middle school students' attitudes towards school.

\section{Methodology}

\subsection{Sample and demographics}

Table 1. General characteristics of research subjects and school sports club participation experience

\begin{tabular}{|c|c|c|c|}
\hline \multirow{2}{*}{ Category } & Frequency (N) & Percentage (\%) \\
\hline \multirow{4}{*}{ Grade } & 1 st & 273 & $27 \%$ \\
\cline { 2 - 4 } & 2 nd & 333 & $33 \%$ \\
\cline { 2 - 4 } & 3 rd & 399 & $40 \%$ \\
\hline \multirow{3}{*}{ Participation status } & Participation & 520 & $52 \%$ \\
\cline { 2 - 4 } & Non-participation & 485 & $48 \%$ \\
\hline \multirow{2}{*}{ Participants' grade } & $1^{\text {st }}$ & 118 & $23 \%$ \\
\cline { 2 - 4 } & $2^{\text {nd }}$ & 183 & $35 \%$ \\
\cline { 2 - 4 } & $3^{\text {rd }}$ & 219 & $42 \%$ \\
\hline \multirow{2}{*}{ Participation period } & $\geq 6$ months & 103 & $20 \%$ \\
\hline
\end{tabular}




\begin{tabular}{|c|c|c|c|}
\hline \multirow{4}{*}{} & $6 \sim 12$ months & 122 & $23 \%$ \\
\cline { 2 - 4 } & $1 \sim 2$ years & 165 & $32 \%$ \\
\cline { 2 - 4 } & $\leq 3$ years & 130 & $25 \%$ \\
\hline \multirow{3}{*}{$\begin{array}{c}\text { In the last year } \\
\text { Frequency of } \\
\text { participation per week }\end{array}$} & 1 time & 148 & $28 \%$ \\
\cline { 2 - 4 } & $2 \sim 3$ times & 189 & $37 \%$ \\
\hline \multirow{3}{*}{\begin{tabular}{c} 
Number of participation \\
\cline { 2 - 4 }
\end{tabular}} & $\leq 4$ times & 183 & $30 \%$ \\
\cline { 2 - 4 } & 1 time & 158 & $39 \%$ \\
\hline
\end{tabular}

\subsection{Methods}

This study revised and used the questionnaire for middle school students' school attitude, which was developed by [9], in consideration of the development level and school characteristics of middle school students. [9] made a questionnaire about school attitude based on a total of 35 questions: 9 questions of students' attitudes towards their school's environment factors, namely school environmental factors that reflect students' attitudes toward the overall physical environment of school, such as the cleanliness and comfort of school facilities, air conditioning and heating, water supply and meal service; 7 questions of school teacher factors that reflect students' preference for subject teachers and homeroom teachers, teachers' teaching styles, and attitudes related to relationships with teachers; 7 questions of school friend factors that reflect preferences for school friends, attitudes related to relationships with friends; 6 questions of school learning factors that reflect the attitudes related to school classes, tasks, tests and scores; 6 questions of school general factors that reflect the attitudes related to school life and school system. As a result of the analysis, a total of 26 questions were classified into four factors: school teacher factors $(22.377 \%)$, school friend factors $(19.383 \%)$, school learning factors $(18.110 \%)$, and school general factors $(16.945 \%)$, and the cumulative variance was $76.815 \%$. The factor loading of each factor was more than .05 , and the reliability was high from .924 to .960 .

\subsection{Data analysis}

The collected questionnaires were coded on a computer and processed by using a SPSS 25.0 statistical program. First, a frequency analysis was conducted to find out the general characteristics of the study subjects and the degree of participation experience in school sports club. Second, an exploratory factor analysis and Cronbach's $\alpha$ coefficient with Varimax rotation were performed for the validity and reliability of the questionnaire questions. Third, independent-samples t-test and one-way ANOVA were carried out to find out the differences in middle school students' attitudes towards school according to the degree of participation experience in the school sports club, and Scheffé test was conducted as a posthoc test. 


\section{Findings}

\subsection{Differences in middle school students' school attitude depending on whether they participate in school sports club or not}

The results of analysis of variance for verifying this fact show that participants in school sports clubs manifested significant differences in all factors by subordinate factors of school attitude as compared with others who do not participate in it. The results are shown in [Table 2].

Table 2. The results of analysis of variance for verifying this fact

\begin{tabular}{|c|c|c|c|c|}
\hline \multirow{3}{*}{ School attitude } & \multicolumn{2}{|c|}{ Participation status } & \multirow{3}{*}{ t-value } & \multirow{3}{*}{$p$} \\
\hline & Non-participation $(n=485)$ & $\operatorname{Participation}(\mathrm{n}=520)$ & & \\
\hline & \multicolumn{2}{|c|}{ Average and standard deviation } & & \\
\hline School teacher & $23.93 \pm 6.02$ & $27.79 \pm 5.42$ & -8.867 & .000 \\
\hline School friend & $27.38 \pm 4.45$ & $28.87 \pm 5.01$ & -3.991 & .000 \\
\hline School general & $23.09 \pm 3.96$ & $24.43 \pm 3.79$ & -4.559 & .000 \\
\hline School learning & $21.09 \pm 4.10$ & $21.99 \pm 4.99$ & -2.627 & .009 \\
\hline
\end{tabular}

\subsection{Differences in middle school students' school attitudes according to the period of} participation in school sports club

As [Table 3] shows, it turned out that there are significant differences in all subordinate factors of school attitude according to the period of participation in school sports clubs.

Table 3. Differences in middle school students' school attitudes according to the period of participation in school sports club

\begin{tabular}{|c|c|c|c|c|c|c|c|}
\hline \multirow{3}{*}{$\begin{array}{l}\text { School } \\
\text { attitude }\end{array}$} & \multicolumn{4}{|c|}{ Participation period $(\mathrm{n}=520)$} & \multirow{3}{*}{$\begin{array}{c}\mathrm{F} \\
\text { value }\end{array}$} & \multirow{3}{*}{$p$} & \multirow{3}{*}{ Post-hoc } \\
\hline & $A(n=103)$ & $\mathrm{B}(\mathrm{n}=122)$ & $C(n=165)$ & $\mathrm{D}(\mathrm{n}=130)$ & & & \\
\hline & \multicolumn{4}{|c|}{ Average and standard deviation } & & & \\
\hline $\begin{array}{l}\text { School } \\
\text { teacher }\end{array}$ & $26.05 \pm 5.23$ & $28.01 \pm 4.28$ & $27.30 \pm 5.68$ & $29.48 \pm 4.56$ & 6.358 & .000 & $\begin{array}{l}A<D \\
C<D\end{array}$ \\
\hline $\begin{array}{l}\text { School } \\
\text { friend }\end{array}$ & $25.98 \pm 4.59$ & $28.64 \pm 4.61$ & $28.96 \pm 5.38$ & $30.80 \pm 4.00$ & 12.761 & .000 & $\begin{array}{c}\mathrm{A}<\mathrm{B}, \mathrm{C}, \mathrm{D} \\
\mathrm{B}<\mathrm{D}\end{array}$ \\
\hline $\begin{array}{l}\text { School } \\
\text { general }\end{array}$ & $22.49 \pm 5.12$ & $23.36 \pm 5.30$ & $24.70 \pm 5.01$ & $26.39 \pm 4.14$ & 9.525 & .000 & $\begin{array}{c}\mathrm{A}<\mathrm{C}, \mathrm{D} \\
\mathrm{B}<\mathrm{D}\end{array}$ \\
\hline $\begin{array}{c}\text { School } \\
\text { learning }\end{array}$ & $20.48 \pm 4.47$ & $21.18 \pm 4.26$ & $22.23 \pm 5.46$ & $23.46 \pm 4.06$ & 6.001 & .001 & $\begin{array}{l}A<D \\
B<D\end{array}$ \\
\hline
\end{tabular}




\subsection{School attitude of middle school students according to the frequency of participation per week in school sports club}

As [Table 4] shows, it turned out that there are significant differences in all subordinate factors of school attitude according to the frequency of participation per week in school sports clubs.

Table 4. School attitude of middle school students according to the frequency of participation per week in school sports club

\begin{tabular}{|c|c|c|c|c|c|c|}
\hline \multirow{3}{*}{$\begin{array}{l}\text { School } \\
\text { attitude }\end{array}$} & \multicolumn{3}{|c|}{ Participation period(n=520) } & \multirow{3}{*}{ F Value } & \multirow{3}{*}{$p$} & \multirow{3}{*}{ Post-hoc } \\
\hline & $\mathrm{A}(\mathrm{n}=148)$ & $\mathrm{B}(\mathrm{n}=189)$ & $\mathrm{C}(\mathrm{n}=183)$ & & & \\
\hline & \multicolumn{3}{|c|}{ Average and standard deviation } & & & \\
\hline $\begin{array}{l}\text { School } \\
\text { teacher }\end{array}$ & $26.01 \pm 5.68$ & $27.65 \pm 5.13$ & $29.23 \pm 5.53$ & 9.338 & .000 & $\mathrm{~A}<\mathrm{C}$ \\
\hline School friend & $27.88 \pm 5.43$ & $28.61 \pm 5.24$ & $29.71 \pm 5.63$ & 3.121 & .045 & \\
\hline $\begin{array}{l}\text { School } \\
\text { general }\end{array}$ & $23.24 \pm 5.02$ & $24.03 \pm 4.15$ & $25.90 \pm 4.70$ & 10.103 & .000 & $\mathrm{~A}, \mathrm{~B}<\mathrm{C}$ \\
\hline $\begin{array}{c}\text { School } \\
\text { learning }\end{array}$ & $20.62 \pm 4.94$ & $21.96 \pm 4.58$ & $22.91 \pm 5.16$ & 5.664 & .004 & $\mathrm{~A}<\mathrm{C}$ \\
\hline & & 1 time $\mathrm{B}$ : & les $C: \geq 4$ & & & \\
\hline
\end{tabular}

\subsection{Differences in middle school students' attitudes towards School according to the frequency of participation in sports club competitions}

As seen in [Table 5], there were significant differences in all subordinate factors of school attitude, based on the frequency of participation in school sports club competitions.

Table 5. Differences in middle school students' attitudes towards School according to the frequency of participation in sports club competitions

\begin{tabular}{|c|c|c|c|c|c|c|}
\hline \multirow{3}{*}{$\begin{array}{l}\text { School } \\
\text { attitude }\end{array}$} & \multicolumn{3}{|c|}{ Participation period $(\mathrm{n}=520)$} & \multirow{3}{*}{ F value } & \multirow{3}{*}{$p$} & \multirow{3}{*}{ Post-hoc } \\
\hline & $A(n=158)$ & $B(n=202)$ & $C(n=160)$ & & & \\
\hline & \multicolumn{3}{|c|}{ Average and standard deviation } & & & \\
\hline School teacher & $26.79 \pm 4.81$ & $27.13 \pm 4.86$ & $29.39 \pm 4.98$ & 9.868 & .000 & $\begin{array}{l}\mathrm{A}<\mathrm{C} \\
\mathrm{B}<\mathrm{C}\end{array}$ \\
\hline School friend & $28.17 \pm 5.08$ & $28.26 \pm 4.61$ & $29.99 \pm 5.07$ & 5.221 & .006 & $\begin{array}{l}\mathrm{A}<\mathrm{C} \\
\mathrm{B}<\mathrm{C}\end{array}$ \\
\hline School general & $21.35 \pm 4.27$ & $21.73 \pm 4.06$ & $22.84 \pm 5.04$ & 3.506 & .031 & $\mathrm{~A}<\mathrm{C}$ \\
\hline $\begin{array}{c}\text { School } \\
\text { learning }\end{array}$ & $22.67 \pm 5.53$ & $24.36 \pm 5.13$ & $26.06 \pm 4.97$ & 12.070 & .000 & $\mathrm{~A}<\mathrm{B}<\mathrm{C}$ \\
\hline
\end{tabular}




\section{Discussion of the results}

The purpose of this study is to identify differences in school attitudes among middle school students in $\mathbf{J}$ Province according to their participation in school sports club, participation period, frequency of weekly participation, and number of competitions. As a result of the study, statistically significant differences were found in all sub-factors of the school attitude according to the participation in school sports club, the period of participation, the frequency of weekly participation, and the number of competitions. This finding shows that middle school students' participation in school sports club has a positive effect on forming a positive attitude towards school. And the subsequent detailed discussions are as follows.

First, the reason why the experience of participating in school sports club positively influences the school teacher factors of school attitude is that the students interact more with their teachers. The study [10], which conducted a qualitative study of the students participating in school sports club for two years, reported that the relationship with teachers improved after participation in school sports club. Because the attitude towards teachers improved as the number of not temporary but continuous interactions increased due to the change of attitude into positive, the decreased prejudice about teachers, and the recognition for teachers. These results are partially same as the previous studies [11][12][13] that have reported that the students who participated in school sports club activities showed better relationships with their schoolmates and teachers, less school violence, and overall satisfaction with school, compared to students who did not participate.

Second, the reason why the experience of participating in school sports club positively influences the school friend factors of school attitude is that participation in the school sports club strengthens social skills. For example, school sports club activities allow the participants to constantly interact with seniors, juniors, and peers, and through such interactions, they can reduce self-centered perspectives. In addition, they go through the social development of learning not only the principles of cooperation, competition and negotiation, but also how to respond to social rules and pressures [14]. It is thought that social skills necessary for interpersonal relationships are acquired through school sports club activities, and interactions with friends is promoted. Young people use social relationships with their parents, teachers, and peers as emotional and psychological resources [15][16], and their social and psychological adaptability improves through interactions such as love, protection, and acceptance of them [17]. Besides, children and adolescents who have positive peer relationships respond appropriately to stressful events, develop positive personalities as they grow, and have successful experience in human relationships [18][19]. Considering this point, the above-mentioned problem of students can be reduced through school sports club activities.

Third, the reason why the experiences of participating in school sports club have a positive effect on the school general factors of school attitude is that the participants may feel grateful to their school. For example, school sports club activities are made by many supports from school, such as human resource support including teachers who directly teach students, physical support for sports equipment and space required for the activities, and financial support for drinks and snacks. This support from school allowed the students who participated in school sports club to feel satisfied and grateful to school and to cultivate a positive attitude towards every situation and environment in school life. The students who feel positive about their school and perceive themselves as active participants in school life are less likely to become academic burnout under academic stresses [20]. When they experience positive emotions about school due to the supportive environment and accessibility, encouragement, 
and kindness from school, they recognize them as valuable and precious people who can be deeply accepted. In this regard, school sports club activities are more important.

Fourth, the reason why the experience of participating in school sports club improved the school learning factors of school attitude is because participation in school sports club strengthens the students' self. For example, according to the study of [21], participation in school sports club competitions provides middle school students with an opportunity to find out the changed result that both they and their team have tried to develop. And regular training and cooperation between team members to prepare for the competitions was found to have a positive effect on self-enhancement. In addition, considering not only the study that reported that there was a positive correlation between academic achievement and self-concept [22], but also the study [23] that eliminated the influence of intelligence index and reported that there was a positive correlation between self-concept and average academic score, it seems that students who participated regularly for a long period of time had a stronger selfconcept, and thus had confidence and necessity for learning, thereby forming a positive learning attitude.

\section{Conclusion}

Two conclusions are suggested as follows.

First, the policy of school sports club should be established from a long-term perspective. Overall, middle school students who participated in school sports club for more than 3 years were significantly higher than middle school students who participated for 1 2 years, 6 12 months, and 6 months or less in all sub-factors of school attitude. However, middle school students who participated for less than 6 months showed the lowest score in all sub-factors, but they were not significantly different from the middle school students who participated for $6 \sim 12$ months and 1 2 years. These results suggest that a positive school attitude is formed by participating in school sports club for at least one year, and students need to participate in school sports club for more than 2 years to show a prominent effect. Therefore, the policy of school sports club should be developed from a long-term perspective. For example, physical education teachers have to bear all the burden of school physical education (PE curriculum, all physical education activities other than the subject). They also should plan and operate all matters including space, sports equipment, time, student motivation, school atmosphere, student record, and sports guidance to run school sports club. This physical education system managed under the sole responsibility is likely to overburden the teachers. It needs to build a system for supporting physical education teachers at national level by improving the environment of school sports club, which relies on the sacrifice and passion of PE teachers, from a long-term perspective. In other words, the policy of school sports club should be established from a long-term perspective, such as securing sufficient budget, constructing and flexibly using a pool of community sports professionals, promoting the positive effects of school sports club activities for parents, students and teachers, and praising physical education teachers for their effort to activate physical education.

Second, it needs to increase the number of school sports club competitions. The results of the study show that the higher the frequency of participation per week and the number of participation in the competitions, the more significant differences appear in all sub-factors of school attitude. Specifically, students have to participate in school sports club four or more times per week in order to form a positive school attitude. And the students' attitude towards school is positively changed only if the cumulative number of participants in the competitions is at least 4 times. Currently, only schools that win or take the second place in city and county 
competitions can participate in provincial competitions, and only the schools that win at each different game of the provincial competition can participate in the national school sports club. Therefore, most students who participate in the school sports club end the competition in early May. The problem is that it is difficult to lead students to participate in school sports club after the competition. Therefore, in order to make students participate in school sports club more than 4 times a week and in the competitions more than 4 times, the number of school sports club competitions must be increased. One way may be holding national school sports club every semester as it currently is, while having league matches or tournaments again at the city and province-level, except for the teams that participate in the upper-level competitions. In other words, a national school sports club competition will be held once a semester, twice a year, and the city and provincial school sports club competition will be held twice a semester or four times a year.

Based on the results and the conclusions of this study, the suggestion for follow-up research is that qualitative research should be conducted on school sports club and school attitude. Since school attitude is about most important factors in school life, such as teachers, friends, and schoolwork, it needs to conduct exploratory research on how school sports club activities help the formation of positive school attitude. This study is thought to provide the clues to alleviate students' emotional problems which are emerging as serious social problems.

\section{References}

[1] Ministry of Education, "Science and Technology, comprehensive measures to eradicate school violence," (2012)

[2] Ministry of Education, Science and Technology, Ministry of Culture, Sports and Tourism, "A study on the activation of elementary and secondary school physical education," (2010)

[3] Ministry of Education, "Plan to activate school physical education in 2016," (2016)

[4] Ministry of Education, "The results of the 2016 Second School Violence Survey," (2016)

[5] Kim H. J., K Y. J., and Cha E. J, "Direction for the activation of the youth volleyball club," Journal of Korean Society of Elementary Physical Education, vol.21, no.1, pp.33-45., (2015)

[6] Park T. I., Cho J. H., Cha U. J., and Kim Y. J, "Participation and personalities relationship of junior high school student sports club using multi-level model," Korean journal of physical education, vol.56, no.5, pp.105-117, (2017)

[7] Yu M. S., Song Y. K., Kim J. Y., Lee J. A., Yang H. I., and Jeon Y. K, “Association of school sport club participation with character, school life satisfaction, life attitude, and educational attitude among school students in korea: a systematic review," Korean journal of physical education, vol.55, no.5, pp.249-262, (2016)

[8] Cha E. J. and Kim Y. J, "Analysis of the differences in personalities of adolescent participating in school sports clubs," Korean journal of physical education, vol.53, no.1, pp.25-34, (2014)

[9] Lim C. H. and Kim S. H, "Development of the school-related attitudes scale for middle school students," Korea Journal of Counseling, vol.10, no.2, pp.1165-1180, (2009)

[10] Lee D. J, "Study on the formation of self-identity of middle school students participating in school sports club,” Ph.D. dissertation, Chonbuk National University, (2019)

[11] Park B. M., Kim D. K., and Heo K, "The difference in school life satisfaction by middle school soccer club participation," Journal of Korean Society Fisheries and Sciences Education, vol.27, no.2, pp.345-352, (2015)

[12] Seo Y. H. and Choi T. H., "The effect of sport club participation for Korea and japan high school students on the school life satisfaction," Journal of Korean Journal of Growth and Development, vol.22, no.3, pp.295-301, (2014) 
[13] Hong J. Y. and Lee D. H, "The relationships of participation in sports clubs and school life satisfaction of elementary school students interpreted from the perspectives of holistic education," Journal of Korean Society for Holistic Convergence Education, vol.19, pp.187-205, (2015)

[14] Kim D. B. and Kwon J. D, "Human behavior theory and social welfare practice," Seoul : Hakjisa, (2005)

[15] Kahn R. L. and Antonucci T. C, “Convoys over the life course: Attachment, roles, and social support," In P. B. Balters and O. Brim (Eds.), Life-span development and behavior, vol.3, New York: Academic Press, (1980)

[16] Weiss R. S, “The provisions of social relationships," In Z. Rubin (Eds.), Doing unto others Englewood Cliffs, NJ: Prentice-Hall, (1974)

[17] Lee J. Y. and Lee J. C, "The effects of parental conflict and social support perceived by high school students on their happiness in school life," Korean journal of youth studies, vol.22, no.5, pp.191-208, (2015)

[18] Coie J. D, “Toward a theory of peer rejection,” New York: Cambridge University Press, (1990)

[19] Rubin K. H., LeMare, L., and Lollis, S, "Social withdrawal in childhood: Developmental pathways to peer rejection," In S. R. Asher and J. D. Coie (Eds), Peer rejection in childhood. New York: Cambridge University Press, (1990)

[20] Shin H. J. and Yu K. L, "Connectedness as a mediator of the relationship between academic stress and academic burnout," Korean journal of youth studies, vol.21, no.1, pp.367-393, (2014)

[21] Kim D. J. and Lee D. J, "The effect of middle school girl student's experience of participation in school sport club on ego-identity," Journal of Korea Association for Learner-centered Curriculum and Instruction, vol.19, no.16, pp.683-700, (2019)

[22] Song I, S, “The higer order structure of self - concept," journal of Korea education psychology, vol.14, no.4, pp.73-103, (2000)

[23] Brookerover W. B., Paterson A. and Thomas S, "Self-concept of ability and school achievement," sociology of education, vol.37, no.3, pp.271-278, (1964)

\section{Authors}

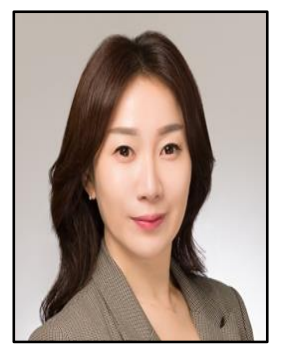

\section{EunJu Lim}

- PhD in education

- Chonbuk National University of Education adjunct professor

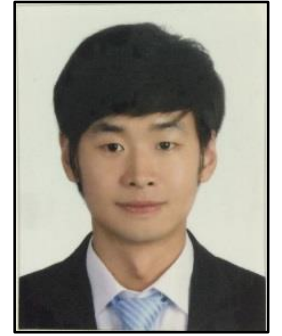

Daejung Lee

- PhD in education

- JeonJu PyeongHwa Middle School (P.E.) Teacher 
The Differences in School-Related Attitudes of Middle School Students in School Sports Club

This page is empty by intention. 